\title{
Remapping Heritage and the Garden Suburb: Haberfield's Civic Ecologies
}

ABSTRACT: Gardens in Australia are considered an important site of heritage maintenance and negotiation for their capacity to materialise transformations in everyday life, design, lifestyles, demographics, environment, as well as social and cultural practices. In the case of conservation areas, gardens tend to be valued in terms of their closeness and potential to preserve specific historical elements. Plants in these gardens are cultivated to evoke period designs, such as Federation (c.18901915) and cottage gardens. In this article we turn to gardens and gardening to make sense of entanglements between cultural, historical and environmental elements, and we ask: what role do plants play in shaping our understanding of suburban heritage? To answer this question, we draw on oral histories, archival research and ethnography in Haberfield, the first model Garden Suburb in Australia. We show how plants channel and mediate multiple concerns that contest and extend ideas of heritage circulating in public discourse. Foregrounding the centrality of plants, this article contributes a dynamic definition of heritage that includes the entanglement of environmental stewardship, individual and collective heritage.

KEYWORDS: design, plants, heritage, gardens, oral history, everyday landscapes 


\section{Introduction}

In Australian cities such as Sydney, neighbourhoods have complex local identities that are based on histories, concepts of heritage, geographies and more-than-human ecologies. In such neighbourhoods gardening is an important practice of environmental, cultural and historical negotiation (Head et al. 2004). In this article we turn to gardens, gardening and plants to make sense of the entanglements between cultural, historical and environmental elements that animate understandings of heritage in the suburb of Haberfield, located on Wangal and Gadigal land.

We chose this as our fieldwork site because Haberfield can be read as an archive of planty relations. The histories in this archive acknowledge the contested and multiple entanglements among plants, humans and other species (Head and Atchison 2009, Head et al. 2014), and between cultural and environmental practices. Haberfield, in fact, is considered a model of the 'Garden Suburb' because of the way it was designed to integrate Federation architecture with specific plants in gardens and streetscapes. The dominance of the Federation style, prevalent from around 1890 to 1915 (Evans 1986), is the reason the identity of the suburb is closely tied to the recognition and conservation of heritage, with the majority of houses protected under a 'heritage order'. Because of their role in the Federation design of the area, plants in home gardens and trees in the streetscape are also an integral component to Haberfield's heritage.

However the original design of the suburb is only one part of the heritage story. A close look at the edges of Haberfield's streets and properties reveals a profusion of diverse botanical life intermingling with Federation plants. Camphor laurels share nature strips with olive trees, tropical varieties such as Spanish moss hang on fences underplanted with parsley and lavender, old roses climb on mangoes, and salad leaves take central stage in garden beds. Low walls revealing immaculately kept lawns are interspersed by 'cottage gardens on steroids' (in the definition of a landscape designer), and container gardens give way to buoyant geraniums spilling over old wooden fences. 
In this paper we take this 'planty exuberance' (Head et al. 2014, 863) as a register to think through notions of suburban heritage. We ask: what can plants tell us about the way heritage is conceptualised, discussed, and practiced in Haberfield?

Although the idea of the Garden Suburb persists in the representation of Haberfield, we suggest that the meaning of heritage has expanded beyond Federation design and stylistic elements (Inner West Council 2019). The Garden Suburb has become a suburb of gardens: in these gardens heritage is contested and relationally enacted through multiple practices. For instance, while some plant species recommended for Federation design in the early 20th century are still present and cared for, other plants provide the possibility of different garden designs that speak to individual interests, taste and histories. In other words, while the status of heritage garden suburb is embraced for strategic reasons by residents, developers, real estate agents, local council and government agencies. the motley flora of Haberfield edges diffracts the vision of pristine Federation-style gardens.

Yet, the prevailing narrative of Haberfield as a Federation suburb contributes to the othering not only of rich and diverse forms of heritage, but also of different stewardship practices and the 'pluralism of environmental relationships' brought by migrant communities (van Holstein and Head 2018). The disconnection between public discourse and living practices is not new. Haberfield gardens remain associated in public representations with Federation garden design (Jackson-Stepowski, Haberfield Association, Burke 1981, Crow 1983 and 1997, Australian Government Department of Environment and Energy 2018, NSW Environment \& Energy 2018). This is despite historical and cultural reasons that complicate the representation of Haberfield as a Federation suburb. For instance, European migrants who settled there after World War Two also influence gardening practices and the proliferation of plant species in Haberfield. More recently, concerns about sustainability circulated in local government policies and initiatives (Inner West Council 2018) influence how people garden. Adding to this variety of practices, plants themselves change gardens over time, migrating over and under fences, hitching rides from birds and bats, or enrolling humans into neighbourly exchanges of cuttings and seeds. 
In this article we point to the gap between how the story of the garden heritage of Haberfield is told as a prime example of Federation style and how it is constituted through the multiplicity of practices and relations between people and plants. To address this gap, we investigated stories of gardening in Haberfield through oral history interviews, and we worked with the community to map the gardens and gardening practices that are important to them. This fieldwork revealed the need for an updated identity for Haberfield that reflects an expanded notion of heritage in the suburb. Such an identity takes into account not only Federation architecture, but also multiple and complex gardening practices of care for the environment intended as the integration of cultural, historical, social and natural elements.

To think through this collection of practices, we draw on Krasny and Tidball's definition of civic ecologies as 'hands-on stewardship practices that integrate civic and environmental values (2015a, xviii).' While an in-depth analysis of Krasny and Tidball's framework $(2012,2015 \mathrm{a}$ and 2015b) goes beyond the scope of this paper, civic ecology remains a fruitful concept for thinking about heritage as an expanded field. Civic ecologies, in fact, bring individual, community, social and cultural elements together with place and the natural environment. A key aspect of civic ecology is that it establishes a nexus between local culture and the urban environment taking as examples self-organised, locally driven, networked stewardship initiatives including community gardening, conversions of industrial areas to nature centres, rooftop gardens, and parklands (Krasny et al. 2015b).

In Haberfield this nexus is especially relevant because heritage and identity are have been historically defined by the idea of the 'garden suburb'. As a consequence, environmental stewardship practices such as gardening or caring for trees on the streets' shoulder, are already part of local cultural practices. In other words, in Haberfield the idea of heritage includes civic ecologies because residents care for the built and natural environment, deriving 'the satisfaction of leaving a legacy for the next generation and making a difference (Krasny and Tidball 2015a, 8)'.

This article also follows an important body of literature on gardening in cities. While this literature is expanding, it predominantly focuses on community initiatives (Holland 2004; Turner et al. 2011; Eizenberg 2013; Cameron and Wright 2014; Nettle 
2014; Lapina 2017; van Holstein 2016, 2017) as noted by Taylor and Taylor Lovell in their study of urban agriculture in the Global North (2013). However, research on residential gardens, particularly in the developed world is increasing. Researchers have shown the plant-human relations in suburban gardens by focusing on material practices (Power 2005), emotional attachment (Bhatti et al. 2009), environmental conservation (Head et al. 2006), sustainability (Ghosh and Head 2009), social, health and environmental benefits (Freeman 2012), and the encounters between the wild and the familiar (Ginn 2016). Taken together these studies show the growing interest in domestic gardens as sites of entanglement between cultural and stewardship practices. We aim at expanding on this body of literature by reading domestic gardens in regard to heritage, and in doing so to foreground the role of plants in defining, conceptualising and contesting prevailing definitions of heritage.

This paper is structured in four parts. Firstly, we locate Haberfield by offering historical context for understanding the importance of plants and gardens in the definition of heritage. In the following section we outline our methodology by describing the three stages of our research: reading the site as an archive; walking and doing sensory ethnography; and listening to oral histories. In the next section we present our analysis of the data through three key findings. Finally, we conclude by linking this suburb-scale study to broader questions of urban sustainability and pointing to the opportunities for further research.

\section{Locating Haberfield, the Garden Suburb of Sydney}

What is now called Haberfield, a suburb on Wangal and Gadigal land, in the Eora nation was colonised by British settlers in the early 1880s. With colonisation, two of the elements that still emerge today in placemaking in Haberfield came into being: real estate and gardening.

In 1806 Ensign Nicholas Bayley of the New South Wales Corps received a 194 hectares land grant, which he ceded to the largest landowner in the colony of New South Wales, Simeon Lord (Jackson-Stepowski 2008). The land became part of Lord's daughter Sarah's dowry in 1825, when Sarah married a medical doctor, David Ramsay. The estate was formally renamed Dobroyde and became locally known as 
Ramsay Bush, because David Ramsay was also an avid botanist. He soon established a plant nursery on the estate, noting that the land was 'one of the finest places in New South Wales, the oranges in the orchard alone being worth $£ 100$ per year' (McMartin 1967). One of the couple's sons, Edward Pierson Ramsay (1842-1916), naturalist, ornithologist, zoologist, founder of the Linnean Society and curator of the Australian Museum (1874-94), continued his father's interest in plants and established the Dobroyd New Plant and Seed Nursery on his share of the estate (Chisholm 1976).

The integration of plants with built architecture took center stage at the beginning of the Twentieth century. In 1901 Richard Stanton bought Ramsay's Bush, and in the following year he added to his holdings with other parcels of land (Figure 1). Stanton was inspired by the vision of people living in spacious homes surrounded by nature laid out in the book To-morrow: A Peaceful Path to Real Reform, published in 1898 by Ebenezer Howard. Stanton designed his development as a garden suburb, contracting several different architects working in what is now known as Federation or Queen Anne style characterised by turrets, gables, asymmetrical elements, verandas that connected house and garden, details of native plants and animals in leadlight windows, plaster detailing, and intricate woodwork (Burke 1981; Betteridge 2001). In line with Federation nation building efforts, some of the ornamental designs of buildings are based on native flora and fauna.

Historian Vincent Crow spells out the role of specific plants in Federation house design:

... the front had a lawn, and garden beds shaped like ovals and circles, sometimes they were crescent shaped, and sometimes they were star shaped. There were a variety of different ones. They were planted with annuals... Then at the back you had the tall trees for a picturesque backdrop. But the backyard had oranges and lemons - citrus trees and fruit trees. So Haberfield was not important just for its Federation houses. It was also the gardens... You can have camellias down the side because they form a frame around the house but they wouldn't block the view from the street... (Crow 2018) 
The plants in the gardens evoked by Vincent Crow, together with the trees planted on the street shoulder to create a canopy, gave a sense of aesthetic continuity and sense of place to the suburb. Government agencies, real estate agents and architectural literature refer to the design and buildings from this period as Haberfield heritage. The suburb is covered by the Haberfield Conservation Area and included in the Australian Heritage Database (Department of Environment and Energy 1991) while individual buildings are listed under the NSW Heritage Act and by Local Government and State Agencies (NSW Office of Environment and Heritage, nd).

However, the garden genealogy of Haberfield is more complicated, pointing to the coexistence of different lineages and forms of heritage. Following the growing body of literature recognising the diverse environmental knowledges and practices of migrant communities (Head et al. 2019), we acknowledge the diverse gardening practices that make up Haberfield heritage. After World War Two people from South Europe, mainly Italy but also Greece and Spain, moved to Haberfield. These migrants, like others (Head, Muir \& Hampel 2004), brought with them different ways of gardening, and new plant varieties. The broad literature on domestic gardening and migration highlights two main issues, which we also found in Haberfield. Gardens are important sites to understand diasporic geographies because on one hand they enable connections with the country of origin, and on the other they are placemaking practices and provide the possibility to reground (Morgan et al. 2005; Graham and Connell 2006). Specific plants recreate smells and flavours: figs, oregano, and olive trees for instance, identify Greek gardens (Armstrong 1998). Migrant gardens also afford a nuanced understanding of migrant communities, because gardening practices are determined not only by ethnicity and cultural background, but also by class, and age (Morgan et al. 2005).

In Haberfield, gardening practices have changed further with demographic change, but gardens remain crucial in defining the suburb. Today, Haberfield's population of around 6,400 residents is older than the average in Australia, with 19.6\% of people aged 65 and over at the 2016 census. $66.6 \%$ of Haberfield residents were born in Australia. The next most common country of birth was Italy at $12.7 \%$, with more than $20 \%$ of the population speaking Italian at home (Australian Bureau of Statistics 2017). 
One resident noted how these demographic changes are reflected in gardening practices, and the annual garden competition documents these variations:

We see many different types of gardens through the competition. There is a concrete garden too, on Hawthorne Parade. The gardeners are music students who have planted all the walls and boulders with plants, put plants in teapots and been really creative. It's the most captivating, fabulous garden. And one year there was a stone garden with a Japanese effect and there was a disquiet amongst the judges because we had departed from the Federation tradition and gone down a new and different line (Maylon 2018).

However gardens usually change more slowly than people. Plants grow in the legacies of past gardening practices and many outlive the residents who first chose them. This brief history shows how gardening is an intrinsic aspect of the heritage of the suburb. The need to preserve and share diverse gardening knowledges and plants, and to consider the legacies of gardens emerged as a key concern among residents and was identified as a strong element in the definition of heritage.

\section{Defining Heritage in Haberfield}

It is very hard not to be a greenie if you are a gardener. We are a fairly politically active community in many ways, because our heritage is at the heart of all this (Maylon 2018).

Maylon spells out the connection between environmental politics, gardening and heritage, and opens up an important question: whose heritage is 'our' heritage? Considering the multiplicity of relationships between people and plants can challenge the problematic notion that Federation is the only available heritage in Haberfield, and that Federation gardens are the valid garden typology. Refocusing on this mutiplicity is important because by concentrating only on Federation style, government agencies (and real estate agents) erase other histories and practices, starting from the much longer Gadigal and Wangal custodianship of the land, and continuing with the heritage of migrant gardeners who arrived in the suburb in the postwar years. Instead, 
the presence of multiform gardening practices suggests a more expansive notion of heritage.

We propose heritage as an expanded field: plants and gardens are at its heart. This understanding of heritage includes a dynamic combination of stewardship, individual and collective practices enmeshed in everyday life in the suburb and produced collectively and relationally by its residents and visitors. Gardening conjugates the love for place with love for the natural environment (Krasny and Tidball 2015a 6, 2837).

In the case of Haberfield, plants shape specific Federation heritage characteristics such as canopies, clear lines of sight, and specific colours and compositions. The residents we interviewed, however, also spoke of their plants in terms of flavours, memories, relationships to wildlife, and interactions with insects, worms and birds. Some examples include: considering plants and flowers as playing an important role in the design of the urban environment; responding to the garden, maintaining green corridors, caring for plants that used to belong to others to ensure a sense of continuity with the past, working with plants, and establishing connections and relations with others mediated by plants.

While this multifaceted understanding of heritage emerges in our fieldwork (as documented in the finding section), it differs from the definition of heritage in Haberfield in the public discourse of organisations, and local, state and federal government agencies. Heritage discourse emerged in the 1960s and 70s predominately as a community and professional reaction to modern architecture and planning (Freestone 1993). This was certainly true in Haberfield, where, from the mid-1970s, residents opposed the destruction of picturesque houses, an early example of community statutory management. As outlined in the Dictionary of Sydney, 'The Haberfield Development Control Plan is regarded as an exemplar, with many conservation area management documents emulating it.' (Sue Jackson-Stepowski 2008). Heritage conservation of this time brought with it terms like 'Federation architecture' (see $1969 \underline{\text { Smith) }}$ which named 'Australian' style, distinct from English and left little room for Aboriginal or the migrant histories touched on above. 
By 1978, two areas in Haberfield were listed by the National Trust of Australia (NSW) as conservation areas for their heritage significance. In 1979, all of Haberfield was listed as a 'classified' conservation area, the Trust's highest listing. While the National Trust 'listing' is advisory and has no legal force, by 1985 the NSW State Government had also created the Haberfield Heritage Conservation Area (HCA) in the Ashfield Local Environmental Plan. HCA listing can protect an area from certain types of development because local planning authorities have a duty to pay 'special attention' to 'character' objectives in the framing and the implementation of their planning policies (Rappaport 2018). When in 1999 the NSW government established the State Heritage Register, Haberfield was not listed. The Haberfield Association has since campaigned for the inclusion of the suburb in this list, with the support of the Inner West Council (Inner West Council 2017).

The plantiness of the suburb is deployed by the Haberfield Association in their community campaigns to draw attention to heritage, together with more traditional forms of political negotiations with local and state government. For example, the annual Garden Competition, Awards Night and Gardens Walk celebrate achievements in private gardens and open these gardens up to a public audience. During Heritage week in 2019, the Haberfield Association also organised an Open Day for the historic garden of Yasmar House, built in 1856-58, which 'has historic and aesthetic value as a now very rare example of the Gardenesque style surviving close to the city on a major arterial road and retaining connection with its original residence (Office of Environment and Heritage NSW Government 2018).' To be alive to this 'planty exuberance' (Head et al. 2014, 863) that has shaped much of Haberfield's history we used a combination of methods, as detailed in the next section.

\section{Methodologies}

On-the-ground fieldwork was undertaken in Haberfield from October 2016 to February 2018, with follow-up site visits continuing through to the time of writing. Our approach reflected and remixed established methodologies in cultural geography, and can be outlined in three stages: archival research; walking (including photodocumentation and observation) and oral histories. Each stage generated data sets that were then triangulated to inform a series of findings. 


\section{The archive}

The first stage was archival research and content analysis of data available in public libraries, private archives, and provided by the Haberfield Association (2015). This content included archived newsletters of the Haberfield Association as well as a register of 125 gardens compiled by the Haberfield Garden Committee, a sub group of the Haberfield Association. This register identified gardeners participating in the Haberfield Celebration of Gardens, over four years and more than 130 gardens of interest. We used Google Maps to translate the data in this register into a digital map (Figure 2), which we shared with the Haberfield Association. This map spatially informs our research while adding to the publically available archive of Haberfield.

In thinking about archives to remap Haberfield as a garden suburb, we turned to Sarah Mills' (2013) conceptualisation of the archive as fragments, objects and ghosts. Archives, she explains, are always fragmentary because they are one version of the past, and because the personal or organisational agendas of their creators is always reflected in the choice of what is archived. To overcome the fragmentary nature of the archive, Mills also offers several strategies, some of which we adopted. One solution is to collect many fragments, from many different sources. Another is to look for and interrogate the cracks (what is missing) in the archive. A third is to piece together a story like a detective from scraps and clues. Archives, Mills continues, are not just textual sources, they are also made of material objects which carry an affective value, bear witness to past events and cultural practices, and become tangible connections with past webs of social and cultural relations (2013, 701-713). Tim Cresswell strengthens the link between materiality and archives by considering a geographical site, Maxwell Street Markets in Chicago, 'as a kind of living archive $(2012,166)$. Cresswell offers several approaches to read the archive such as accepting its incompleteness and messiness and reading it 'against the grain' to find unofficial stories hidden in its gaps. This approach requires understanding what is not included in the archive and working with these gaps. The other is to read it 'along the grain' to understand the historical power structures that shaped the archive (167).

Drawing on these ways to think about the archive of Haberfield we collected fragments from multiple sets of materials: the historical writing produced mainly by local historians and concentrating on the Federation years such as entries in 
dictionaries and books on the suburb's history; publicly available historical images and brochures; photographs our participants showed us; and the Haberfield Association's archive consisting of newsletters and records of the garden competition. We also considered Haberfield as a living archive, made of the topography, visual and material culture, architecture and plants, and we explored it by walking.

The archive, when read along the grain, returned a vision of Haberfield as the Federation garden suburb. Local histories (Crow 1978, 1983, 1997), street signs and commemorative plaques, billboards advertising expert heritage renovation, Queen Anne architectural and decorative elements, some elements of garden design such as front garden flower beds, curved driveways flanked by small flowering annuals, photographs, and the record of winners of the Haberfield garden competition locate the suburb's heritage in the Federation years.

Reading the archive against the grain and paying attention to the omissions, on the other hand, reveals the presence of migrant heritage formations. A preference for red brick as building material of choice, white columns, the occasional plaster lion, olive, mango and citrus trees, shops, edible plants, garden statuary disclose the influence of Southern European migration. This is confirmed by the record of the Haberfield Garden Association, which in a period of 15 years shows 35 Italian gardeners entering the competition. None ever won. It was later explained in an interview that Italian gardens do not comply to Federation aesthetic criteria and are therefore disqualified from entering the main prize. The category 'vegetable garden' was added to the competition in 2018 in order to include migrant gardeners. There is no category for native gardens or acknowledgement of local plants in the competition which points to an erasure of Indigenous heritage from the landscape and the archive.

The question of how Gadigal and Wangal heritage relates to the archive of Haberfield is difficult to answer and is part of important and ongoing work on incorporating Indigenous perspectives and knowledges into Australian archives (Faulkhead et al. 2010). Concepts of heritage should not only include Indigenous knowledges but fully respect and support self-determining Indigenous-led practices and processes. On one hand we can speculate that, as it happened in other areas in the Sydney basin, along the coastline and waterways, Country in Haberfield was cared for and tended. But as 
far as we know, the details of land and environment practices are not recorded: there are no immediate references in archival records, nor visible archaeological sites. While embarking on such research is beyond the scope of this study, the archive of Haberfield is incomplete without recognition that entangled relationships between people and plants go back well before colonisation.

\section{Walking}

The second stage of the study involved iterative walks to help us identify gardens of interest, plants that had escaped gardens, and patterns of environmental stewardship across the suburb. Our walking methodology aligns with others who underscore the value of walking to the study of place and its relationship to sensory ethnography. (Springgay \& Truman 2017). As we walked we observed, touched, smelled, and tasted plants, documented gardens and streetscapes with photography and notes and conducted over the fence interviews. Going 'over' the fence means transgressing the boundaries of private property in order to observe more than human trajectories and ecologies that are not contained by private 'gardens'.

While walking, we use Map My Walk, a mobile phone application designed for tracking routes to 'know where you're going, see where you've been' (Map My Walk, n.d.). This tool is important on a pragmatic level because it helps to retrace our steps in order to organise follow up visits and interviews at sites of interest and on a conceptual level because it generates our own embodied research archive. We also use photography to frame what we are looking at, literally, and to record our observations. Instagram is used as a form of collaborative notetaking and a way to share our walks and our observations with each other. We use hashtags, such as \#mappingedges, \#giardino and \#haberfieldgardens to connect to others making relevant observations.

\section{Oral Histories}

The third and final research stage was informed by the first and second, which helped us formulate a set of questions to conduct oral history interviews with nine gardeners recruited through the Haberfield Association, among participants of the annual Haberfield Garden Competition, and other social networks. These questions explored three conceptual areas: the cultural history of the gardeners and garden, the actual 
garden, as design and gardening practices, and the social encounters and relations generated in and by gardens.

Oral history as a methodology differs from ethnographic interviews not so much because of a chronological distance from the events that are discussed, but because oral history is a method based on participatory storytelling. The format of an oral history interview is unstructured and meandering: it involves many tangents and does not necessarily follow a chronological order. Historian Alessandro Portelli describes a significant aspect of oral history as the 'work of relationships' between past and present, memory and narrative, interviewer and interviewee, and orality and written or recorded narrative $(2009,21)$.

To this we add that garden oral histories are also about relationships between humans and plants. We interviewed participants in their homes and in their gardens. Plants often interrupted the direction of narrations, and prompted short stories, in which they played cameo roles. As well as listening to people's stories, we were observing, touching, smelling, tasting, and listening to their gardens. The interviews were then transcribed and content coded. Edited versions were sent to participants to ensure they recognised the tone and the voice, as well as content, as their own. They were also invited to reedit the interviews. In this article excerpts from these edited oral histories are used to guide our findings.

Debates on the use of oral histories in geographical research emphasise how this method can illuminate the complexities of place and diverse identities. Oral histories can also illuminate scale, and bring to the fore the relational character of place, revealing how local experiences are entangled with larger formations: 'localized as place can be to the individual, there are political, social and economic elements that connect individual places to a wider network of activity present at a larger scale (Ward 2012, 139).' Geographers Harvey and Riley stress the importance of the use of oral histories to study place. First, oral histories provide non-mainstream knowledge on localised issues that can inform policy decisions with a point of view 'from below'. Second, they can inject critical voices in debates on landscape conservation dominated by superficial mainstream narratives. In summary, oral histories can both 
challenge superficial narratives about place, and animate narratives of the past (Harvey \& Riley 2005, 19).

In the context of the narrativisation of Haberfield as the garden suburb oral histories proved useful to bring to the surface more complex definitions of heritage in relation to civic ecologies. While the garden suburb status was embraced by all participants, oral histories revealed how the garden suburb is lived and practiced in everyday lives. In this sense oral histories offered a more nuanced and layered understanding and in challenged the definition of heritage as 'Federation heritage', revealing the role played by plants in the making of Haberfield's living heritage.

\section{Findings}

Gardens are crucial to Haberfield identity. I am just concerned for the future. The value of properties have doubled and tripled in price in the last 20-30 years. When money comes into a place it becomes difficult to tell people what to do. (Maylon 2017)

People often say Haberfield is the garden suburb, so I think a lot of people get the idea that we all have really grand gardens, but we don't. All we are is just a regular suburban spot. The whole point was that when Richard Stanton did the development in about 1901, he laid down that each house had to have a garden, as opposed to all the small terrace houses in nearby Glebe and Leichhardt. (Hill 2018)

As outlined by Maylon and Hill in their oral histories, gardens, whether imposing or 'mundane task-scapes, replete with watering cans and jobs undone, that move to rhythms of everyday life' (Ginn 2014, 229), play an important role in placemaking, and in the identity, history and heritage of Haberfield. Our findings show that plants are also catalysts for those forms of stewardship that conjugate cultural and environmental aspects.

Residents agree that the suburb is undergoing disruptive changes that threaten its heritage. A motorway, for instance, wanted by the New South Wales state government and built at the eastern edge of the suburb by the company WestConnex, 
destroyed entire streets, homes and gardens in Haberfield. In the same period one of the Australian energy companies cut down several of the old trees lining the streets according to Stanton's original vision of the garden suburb. Long-term residents move out or pass away and a new demographic bracket is moving to the suburb, as Maylon recounts in the oral history quoted above. Several participants expressed the fear that the arrival of a new generation of middleclass homeowners working long hours to pay huge mortgages will mean gardening practices in the suburb will be neglected.

The profusion of plant newcomers, such as Photinia robusta, widely used for fast growing hedges that can create privacy and control noise, was cited as a reason of concern, particularly as tall hedges disrupt the Federation eye line of properties. Participants worried that hedges indicated that Haberfield's history and heritage may soon be lost. Others more optimistically pointed out that young people garden creatively, bringing in new plants and new ideas, and that students renting some of the properties are actively interested in vegetable gardens as a lifestyle choice.

In the face of these changes, the shared love of nature and place, and the care for the plant companions that contribute significantly to shape the heritage of Haberfield bring residents together. In her research on Newtown and Erskineville, nearby neighbourhoods to Haberfield, also middle class and recently gentrified, van Holstein (2017) identifies an intersection of collectivist and individual objectives regarding food production in community gardens. Similarly in Haberfield, the drive to maintain plants in home gardens, and trees and plants in the streetscape generates dynamic, activities that bring together individual and collective concerns.

In the following sections we present our findings, organised around the three main and interlinked themes. By focusing on plants and gardens, we establish how residents expand the notion of heritage beyond conservation of Federation architecture, enacting heritage relationally through gardening practices. Gardening as individual and collective heritage as well as a forms of stewardship emerge in the exchanges with the nine participants quoted at length here: Bennet (A. and B.), Constantopedos, Crow, Gallinaro, Hill (R. and G.), Kidd, and Maylon. These oral histories were recorded in gardens where plants are at the centre of the conversations. 


\section{Plants, Gardens and Stewardship}

We also think about other inhabitants of the garden, so we planted grevilleas to attract birds and bees. Parrots love the two palm trees at the front, my cabbage palm and my Washingtonia. Those trees are precious and they are older than the house, so you can see them from miles away. The parrots get up there and knock the bark off and have a good time. I have changed my garden over time to support other creatures. (Maylon 2018)

In Haberfield, stewardship is an important aspect of gardening. As described in the quote above, specific flowers, trees and shrubs are chosen for their capacity to support other species in the suburb, such as birds, insects, and of course, other plants. Many gardeners described working with microclimates or 'garden rooms', using more robust plants to protect others from the heat and designing the entire garden as a cool place.

One of the recurrent themes in our interviews is the importance of gardens in the local ecology and caring for one's own garden is often seen as a significant contribution to the environment.

So the design is not just about resilient plants, it is also about the wildlife that come here. We have an array of birds, hundreds of visiting birds. We have ibis that come and walk around our back yard. They fly in because or during the drought. I come out when I lock up the chooks and I disturb the flying foxes and brush-tailed possums that are up in the trees. We have an osprey eagle that comes here to catch the rats in the chicken coup. We call the top of that fence that goes all the way down to the canal, the 'Rat Highway'. Pigeons and turtle doves come in to get their feed as well. They are all very happy.

(Constantopedos 2018)

Gardeners spoke of the joy in maintaining 'inherited trees' which were then visited by native wildlife, especially birds. People also plant trees to attract birds, flowers to attract bees, and keep water gardens to encourage frogs. 
The attachment to birds in Haberfield indicates an understanding of trees being situated within urban wildlife corridors, as Angie explained: 'I like this idea of connecting trees to allow the bird life to be able to travel from one tree to another. You see, even that corner over, there are five gumtrees in a row. The bird life! (Gallinaro 2018). Rather than feeding birds, people were more interested in creating habitats, understanding active bird life as a sign of successful environmental stewardship. 'It doesn't take much to attract birds, just make it safe for them and provide some water.'

Many gardens in Haberfield are designed with sustainable systems in mind, particularly rainwater and foods scrap collection. A retired journalist, for example, lifting the lid of his compost bin, confessed 'I've become a real enthusiast about compost and worms'. He had experimented with different systems, researching on the internet and talking to fellow gardeners, until he found the one that worked best for his garden and his lifestyle. He also designed his own rainwater collection system, which required daily tending, but didn't require a bulky tank.

Other gardeners also described tinkering with systems:

We try to be green. We recycle all our foodstuff. We have a compost bin. Also our chooks are ideal for composting and they have a huge chicken run. We water using our rainwater tank. We have a hive of native bees to help with the cross pollination of our vegetables. (Constantopedos 2018)

\section{Plants, Gardens and Individual Heritage}

My mother was a gardener. We were laughing recently because we were at the botanic gardens with the boys and it prompted a memory - because mum would have me on lookout while she took a little snippet of something to propagate. And when my son was little, there used to be a guava tree at the school, and the teacher was looking out the class window and said 'There's Liam's mum leaping for guavas'. Well I was going to make guava jelly. I suppose for both of us, it's nostalgia that drives our gardening efforts. (Bennet 2018) 
A key aspect of civic ecology is the capacity to mobilise memories, as practices are passed down to others, both in time and space (Krasny \& Tidball 2015, 66-73). In our conversations all participants framed their love for nature and gardening in their personal heritage. Maylon, as an example, connected his passion ('my garden is my castle', he says) with his family history, which also happens to intersect with the history of roses, as he explains:

Gardening has been part of my family history for a long time, starting in the mid 1880s. I am the great-grandson of Henry Bennett, who in the 1880s was recognised for creating a new class of roses called Hybrid Tea. I have two of his roses in my garden now. They came from my mother's garden in Queensland. (Maylon 2018)

Other gardeners evoked their parents' plants and the gardens of their childhoods as the sites where their interest in gardens started, and many drew links to their family heritage and history. In some cases, plants embody 'domestic cultures of memory and commemoration' (Ginn 2014). One gardener had planted trees for the people who had been important in her life: 'A lot of my plants also are memorials' (Gallinaro 2018). In some cases specific plants were cherished as the keepers of family memories, as illustrated in this excerpt:

Dad was very big on hanging pots and baskets and he had a shade house that he built himself many years ago. When they died and we sold the house we brought some of the pots back here with us. You can see the ones that are hanging off the branches of the trees and the ferns over against the fence, they're on a shelving system on three levels. They all came from Five Dock. (Hill 2018)

As well as creating relations with individual heritage, plants were described also as conduits in the education of new generations. Constantopedos, who taught her granddaughter to rub leaves in her hands and recognise the smell of herbs, says:

I think about my garden as a feast for the senses; with lots of flavours and scents. I am teaching my granddaughter to smell the garden, and we are 
constantly crushing the foliage and flowers of everything (Constantopedos 2018).

In all our oral histories gardeners connected their edible plants to food heritage, and considered the shifts in public discourse towards home grown vegetables. 'We have spinach risotto once a fortnight, which is a traditional Greek dish', explained Constantopedos (2018). Growing vegetables, however, prompted also reflections on changing food practices, pointing to the dynamic understanding of how plants are used in Haberfield. This shift also illustrates how the value attributed to some plants, and with it garden design, change over time. For example, Constantopedos continued, what is understood as edible has changed and brought attention to his own cultural heritage: 'The Mediterranean diet is very good and it includes lots of edible weeds or wild greens' (Constantopedos 2018). Pointing out violets and nasturtiums, plants that had 'always been there', Bennet explained how one plant had undergone a recent reconceptualization: 'Fifteen years ago we would have said "we've got flowers all through the back", but now we have 'salad ingredients (Bennet 2018).'

\section{Plants, Gardens, and Collective Heritage}

Gardens are massively important for the identity of Haberfield as a suburb. (Gallinaro 2018).

I think there is a role for the Haberfield Association to give information about our history, why this is a garden suburb and what is the importance of a garden suburb. We are the best living example of the Stanton ideal of garden suburb, which was also an ideal in England and in North America in the same era. We have now established that we are probably the world's oldest garden suburb. (Maylon 2017)

While the analysis in the previous section offers examples of individual heritage, these are not practiced in isolation, rather they converge in an idea of collective, dynamic, and responsive heritage we interpret alongside civic ecology. Heritage therefore, is not just about individual houses and streetscapes, it is about a sense of place that is produced through social relations and everyday practices. 
This relational character is exemplified in the maintenance of collective heritage. Regular initiatives such as monthly meetings, working bees, a new street seed library, and the annual garden competition strengthen relationships and the sense of community. Residential gardens offer opportunities for wellbeing, and are sites where specific plants are cultivated drawing on personal memories. But residential gardens are also the place where ecosystem services are provided, for instance in the maintenance of trees that together and across individual gardens' boundaries create green corridors for native wildlife. Similarly, native plants that grow in public spaces cross over into private gardens. Grasses, as an example, offer the opportunity to draw on local biological memories (Krasny and Tidball 2015a, 7) and to learn about the local environment (4-11), as one of the gardeners who participated in this project, recounts:

I decided to go to a Bush Care walk down Hawthorne Canal where Adam Ward brought to my attention the native grass. Its common name is a weeping rice [Microlaena stipoides]. I ended up sourcing some seeds and sowing them - and it seems to be working. So that's a real success story. (Gallinaro 2018)

A key event to enact forms of collective garden heritage is the Gardening Competition, run every year by the Haberfield Association. This event fulfils an important role that is more about collaboration and sharing and socialising than it is about competing, and it 'provides a means of collaboration between gardeners. People get to know each other and can exchange gardening information (Crow 2018).' Says one participant:

We did well at the last Haberfield Association's garden competition. We did not enter it to win, just to participate and see other people's gardens...

Everybody who takes part all love looking at everybody else's gardens, and we've met so many people. It's not a very big suburb, so the same sort of people often enter each year, but you always get new ones and it surprises us all sorts of people and gardens (Constantopedos 2018).

And: 
My neighbour's garden is just stunning. It's an inspiration and I can see it over the fence. It's a vegetable garden. There's a macadamia tree in there, which is very exciting and my passion fruit grows up through it and my wisteria. They have chickens too (Kidd 2018).

Sharing ideas, knowledge, and opportunities for learning is important to people: 'Collaboration is important to gain knowledge about local gardens, what grows well in them and what does not' (Crow 2018). Another said: 'We're always swapping notes and swapping plants' (Gallinaro 2018). People also spoke about physically exchanging gardening materials, cuttings, seeds and about their gardens as places to share and to connect with neighbours: 'People visit and take cuttings home with them' (Constantopedos 2018). Gardens are also understood as a form of exchange: 'We had 100 grapefruits last season. We eat them, and we gave them away to people' (Kidd 2018). Sometimes plants cross garden fences and generate good neighbourly relations: 'Our neighbour at the back is Italian and has a lovely mango tree. The chicory came under the fence, from her garden, but we let it runaway and it's lovely (Bennet 2018).' At other times plants generate fence wars, because they block visibility, or litter neighbours' properties (we cannot report specific examples because of legal reasons).

And gardeners also understood their plants as a way to connect with strangers and to foster serendipitous relations in the suburb. These exchanges were described with a sense of reciprocity:

Sometimes I will be out somewhere and I'll admire a plant, and they will say "Help yourself." We have rosemary at the front that we have growing. I wish people would just take that. There's bushes of the stuff. Why would anybody buy a bunch of rosemary for one lamb roast? It's silly, isn't it? (Bennet 2018)

Sharing cuttings, produce, seeds and knowledge, meeting for coffee to talk about gardens, walking together, chatting over fences, as well as more formal meetings and shared projects were seen to improve the acknowledgement of collective heritage. 
In addition to recognising gardens designed and cultivated according to diverse cultural blueprints, a clear shift in thinking about heritage as something dynamic was identified by a number of participants. 'The debate used to be about whether or not aesthetic changes were in the spirit of the early twentieth century, but people aren't living in the early twentieth century anymore (Bennet 2018).' They emphasised the way gardens act as sites of living heritage. Gardens 'enhance the appearance of the property and put into practice the concept of Haberfield the Garden Suburb (Crow 2018).'

And yet there were tensions expressed between the desires of distinct households and the shared identity of the suburb. 'Our personal preference would be for native plants, but not here - this is a Federation garden (Constantopedos 2018).' This shared identity is facilitated by the Haberfield Association, its garden competition that enables people to visit and see others' gardens, as well as informal social relations:

The Haberfield Association's garden committee congratulated us because we have preserved characteristics of the Federation garden, by keeping many of the heritage trees and plants we have found, even if it is adapted in a less formal and more cottage garden way, so that there are no hedges, for example. We prefer a more relaxed and casual plan, and the result is that the plants are eclectic and resilient, including both natives and Federation plant types. (Constantopedos, 2018)

\section{Conclusion}

This article has considered the role of plants in shaping suburban heritage in Haberfield, a conservation area in Sydney's Inner West. This lens has enabled us to define heritage as relationally constituted in personal, collective and stewardship practices. In this was we have articulated the coming together of socio-cultural and environmental concerns, defined as civic ecologies following Kransy and Tidball (2015a and 2015b).

An iterative methodology comprising archival research, walking and photodocumentation, as well as collaborative oral histories has facilitated a fundamental 
analysis of the connections between gardening, environmental stewardship and heritage within the civic ecology of Haberfield. For the significance of these connections to be fully realised, Haberfield needs to be read as a place valued for its heritage, and against the backdrop of the history of entanglements between plants, gardens and the built environment. These histories reveal that gardens are an intrinsic element in the way the suburb is identified, talked about and lived in. More importantly, while home gardens are places of decision making at a household level and expressions of priorities and preferences (Red roses or white roses? Edible or decorative foliage? Fruit trees or natives?), they are also places of intersecting intentions. Residents in Haberfield remind us that while their home gardens are private and personal, they simultaneously generate collective ideas of heritage.

Furthermore, as sites of environmental stewardship home gardens in Haberfield create and preserve wildlife corridors, encourage plant sharing, and create social networks of care. We recognise in these practices both the physical work done by gardeners in their own homes as well as the social work done by informal groups such as neighbours swapping seeds and cuttings. More formal organisations such as the Haberfield Association also play an important role in generating the civic ecology of Haberfield.

While limited in geographical scope, this research demonstrates that Haberfield is an important site for untangling the 'simultaneity of stories-thus-far' (Massey 2005, 9) that relate to heritage in a particular neighbourhood. This invites further work that could include more demographically diverse human participants as well as the inclusion of more species in researching how heritage is constituted relationally.

\section{References}

Armstrong, H. (1998). Migrants' Domestic Gardens: A People Plant Expression of the Experience of Migration. In T. \& W. Burchett (Ed.), Proceedings of International Conference, Towards a New Millennium in People-Plant Relationships: 28-35. Sydney: University of Technology Sydney.

Australian Bureau of Statistics (2017). 'Haberfield (State Suburb)', available from: http://quickstats.censusdata.abs.gov.au/census services/getproduct/census/201 6/quickstat/SSC11828 (accessed 14 March 2018.) 
Bennett, N. J., Whitty, T. S., Finkbeiner, E., Pittman, J., Bassett, H., Gelcich, S., \& Allison, E. H. (2018). Environmental Stewardship: A Conceptual Review and Analytical Framework. Environmental Management, 61(4): 597-614. https://doi.org/10.1007/s00267-017-0993-2

Betteridge, C. (2001). Federation gardens. Reflections: The National Trust quarterly, (May-July 2001), p.8.

Bhatti, M., Church, A., Claremont, A., \& Stenner, P. (2009). 'I love being in the garden': enchanting encounters in everyday life. Social \& Cultural Geography, 10(1): 61-76. https://doi.org/10.1080/14649360802553202

Burke, S. 'The Development of The Garden Suburb Idea before the Great War and the conservation of Haberfield', University of Sydney thesis, 1985.

Cameron, J., Gibson, K., \& Hill, A. (2014). Cultivating hybrid collectives: research methods for enacting community food economies in Australia and the Philippines. Local Environment. https://doi.org/10.1080/13549839.2013.855892

Cameron, J., \& Wright, S. (2014). Researching diverse food initiatives: from backyard and community gardens to international markets. Local Environment, 19(1): 1-9. https://doi.org/10.1080/13549839.2013.835096

Chisholm, A. H. (1976). Biography - Edward Pierson Ramsay - Australian Dictionary of Biography. Retrieved August 16, 2018, from http://adb.anu.edu.au/biography/ramsay-edward-pierson-4446

Cresswell, T. (2012), 'Value, gleaning and the archive at Maxwell Street, Chicago', Transactions of the Institute of British Geographers, 37: 164-76.

Crow, V. (1978). Haberfield: the development of its character. Ashfield NSW: Ashfield and District Historical Society.

Crow, V. (1983). Haberfield, the Federation Suburb. Ashfield NSW: Ashfield and District Historical Society.

Crow, V. (1997). Haberfield: Distinctly Australian. Haberfield NSW: V. Crow.

Crow, V. (2002). Tours of Haberfield: Past and Present. Haberfield NSW: V. Crow.

Department of Environment and Energy, 1991. 'Haberfield Conservation Area, Haberfield, NSW, Australia', available from https://www.environment.gov.au/cgi-bin/ahdb/search.pl (accessed 15 August 2018).

Eizenberg, E. (2013). From the ground up: Community gardens in New York City and the politics of spatial transformation. Farnham, Surrey: Ashgate Publishing Company. 
Evans, I. (1986). The Federation House: A restoration guide. Flannel Flower Press.

Faulkhead, S., Iacovino, L., McKemmish, S. and Thorpe, K. (2010). Australian Indigenous knowledge and the archives: embracing multiple ways of knowing and keeping. Archives and manuscripts, 38(1): 27-50.

Firth, C., Maye, D., \& Pearson, D. (2011). Developing "community" in community gardens. Local Environment, 16(6): 555-568. https://doi.org/10.

Ghosh, S., \& Head, L. (2009). Retrofitting the suburban garden: Morphologies and some elements of sustainability potential of two Australian residential suburbs compared. Australian Geographer, 40(3): 319-346. https://doi.org/10.1080/00049180903127754

Ginn, F. (2014). Death, absence and afterlife in the garden. Cultural Geographies, 21(2): 229-245. https://doi.org/10.1177/1474474013483220

Ginn, F. (2016). Domestic wild: Memory, nature and gardening in Suburbia. Domestic Wild: Memory, Nature and Gardening in Suburbia. London \& New York: Routledge. https://doi.org/10.4324/9781315577975

Graham, S. \& Connell, J. (2006). Nurturing relationships: The gardens of Greek and Vietnamese migrants in Marrickville, Sydney, Australian Geographer, 37(3): 375-393.

Harvey, D., \& Riley, M. (2005). Country stories: the use of oral histories of the countryside to challenge the sciences of the past and future. Interdisciplinary Science Reviews, 30(1). https://doi.org/10.1179/030801805X19681

Head, L., Muir, P., \& Hampel, E. (2004). Australian Backyard Gardens and the Journey of Migration. Geographical Review, 94(3): 326-347. https://doi.org/10.1111/j.1931-0846.2004.tb00176.x

Head, L., \& Atchison, J. (2009). Cultural ecology: emerging human-plant geographies. Progress in Human Geography, 33(2): 236-245. https://doi.org/10.1177/0309132508094075

Head, L., Atchison, J., Phillips, C., \& Buckingham, K. (2014). Vegetal politics: belonging, practices and places. Social \& Cultural Geography, 15(8), 861-870. https://doi.org/10.1080/14649365.2014.973900

Head, L., Klocker, N., \& Aguirre-Bielschowsky, I. (2019). Environmental values, knowledge and behaviour: Contributions of an emergent literature on the role of ethnicity and migration. Progress in Human Geography, 43(3): 397-415. https://doi.org/10.1177/0309132518768407

Inner West Council (2017). 'Council Advances State Heritage Listing of Haberfield'. viewed 31 November 2018, https://www.innerwest.nsw.gov.au/about/news/media-releases/2017-mediareleases/council-advances-state-heritage-listing-of-haberfield 
Inner West Council. (2019). Heritage publications. viewed June 21, 2019, from https://www.innerwest.nsw.gov.au/develop/planning-controls/heritage-andconservation/heritage-publications

Jackson-Stepowski, S., (2008). Haberfield. Sydney Journal, 1(2).

Krasny, M. E., \& Tidball, K. G. (2012). Civic ecology: a pathway for Earth Stewardship in cities. Frontiers in Ecology and the Environment, 10(5): 267273. https://doi.org/10.1890/110230

Krasny, M. E., \& Tidball, K. G. (2015a). Civic Ecology. Adaptation and Transformation from the Ground Up. Cambridge MASS and London: The MIT Press.

Krasny, M. E., Silva, P., Barr, C., Golshani, Z., Lee, E., Ligas, R., ... Reynosa, A. (2015b). Civic ecology practices: Insights from practice theory. Ecology and Society, 20(2). https://doi.org/10.5751/ES-07345-200212

Lapina, L. (2017). 'Cultivating Integration'? Migrant Space-making in Urban Gardens. Journal of Intercultural Studies, 38(6): 621-636. https://doi.org/10.1080/07256868.2017.1386630

McMartin, A. (1967). Ramsay, David (1794-1860). Retrieved July 30, 2018, from http://adb.anu.edu.au/biography/ramsay-david-2571

Mapping Edges. 'Home Gardens of Haberfield' Available at http://www.mappingedges.org/project_category/home-gardens-haberfield/, accessed August 152018.

Massey, D. (2005). For Space. London: Sage.

Mills, S. 2013, 'Cultural-Historical Geographies of the Archive: Fragments, Objects and Ghosts', Geography Compass, 7(10): 701-13.

Morgan, G., Rocha, C., \& Poynting, S. (2005). 'Grafting Cultures: Longing and Belonging in Immigrants' Gardens and Backyards in Fairfield'. Journal of Intercultural Studies, 26(1-2): 93-105. https://doi.org/10.1080/07256860500074094

Murphy, M. A. (2017). Dwelling Together. Space and Culture, 20(1): 4-23. https://doi.org/10.1177/1206331216643782

Nettle, C. (2009). Growing Community: Starting and Nurturing Community Gardens. Adelaide: Health SA, Government of South Australia and Neighbourhood Houses and Centres Association Inc. Retrieved from https://books.google.com/books?id=4o69Qp3y1f0C\&pgis=1

NSW Office of Environment and Heritage, no date, available at https://www.environment.nsw.gov.au/heritageapp/heritagesearch.aspx (accessed August 25 2018). 
Power, E. (2005). Human-Nature Relations in Suburban Gardens. Australian Geographer, 36(1): 39-53.

Rappaport, P. (2018). 'The Purpose of Heritage Conservation Areas' viewed 31 November 2018, https://www.heritage21.com.au/the-purpose-of-heritageconservation-areas/

Riley, M. \& Harvey, D. 2007, 'Talking geography: On oral history and the practice of geography', Social and Cultural Geography, 8(3), pp. 345-51, viewed 31 May 2018, <https://www-tandfonlinecom.ezproxy.lib.uts.edu.au/doi/pdf/10.1080/14649360701488765?needAccess $=$ true $>$.

Smith, B. (1969) Architecture in Australia, Australian Historical Studies, 14(53): 8592, DOI: $10.1080 / 10314616908595410$

Springgay, S. and Truman, S.E., (2017). Walking methodologies in a more-thanhuman world: Walkinglab. Routledge, London.

Taylor, J. R., \& Lovell, S. T. (2014). Urban home food gardens in the Global North: research traditions and future directions. Agriculture and Human Values, 31(2), 285-305. https://doi.org/10.1007/s10460-013-9475-1

The Haberfield Association, 2015 'About Us' http://haberfield.asn.au/about_us/ (accessed August 15 2018).

Turner, B., Henryks, J. and Pearson, D. (2011) 'Community gardens: sustainability, health and inclusion in the city', Local Environment, 16:6: 489492, DOI: $\underline{10.1080 / 13549839.2011 .595901}$

van Holstein, E. (2016). 'Transplanting, plotting, fencing: relational property practices in community gardens'. Environment and Planning A: Economy and Space, 48(11): 2239-2255.

van Holstein, E., 2017. Relating to nature, food and community in community gardens. Local Environment, 22(10): 1159-1173.

van Holstein, E., \& Head, L. (2018). Shifting settler-colonial discourses of environmentalism: Representations of indigeneity and migration in Australian conservation. Geoforum, 94(April), 41-52.

https://doi.org/10.1016/j.geoforum.2018.06.005

Ward, A.R. 2012, 'Reclaiming Place through Remembrance: Using Oral Histories in Geographic Research', Historical Geography, 40: 133-45, viewed 31 May 2018, $<$ https://ejournals.unm.edu/index.php/historicalgeography/article/view/1348/ht $\mathrm{ml}>$. 


\section{Oral Histories}

Constantopedos, T., Crosby, A. \& Vanni Accarigi, I. (2018). Responding to the garden: a conversation with Takis Constantopedos - Mapping Edges. Retrieved August 17, 2018, from http://www.mappingedges.org/project/responding-to-the-garden-aconversation-with-takis-constantopedos/

Bennett, A., Bennett, B., Crosby, A. \& Vanni Accarigi, I. (2018). Plants that know where to grow: a conversation with Aine and Barry - Mapping Edges. Retrieved August 17, 2018, from http://www.mappingedges.org/project/plants-that-know-where-to-grow-aconversation-with-aine-and-barry/

Crow, V., Crosby, A. \& Vanni Accarigi, I. (2018). The garden suburb: a conversation with Vincent Crow - Mapping Edges. Retrieved August 17, 2018, from http://www.mappingedges.org/project/vincent-crow-garden-suburb/

Gallinaro, A., Crosby, A. \& Vanni Accarigi, I. (2018). Trees, urban gardening and the importance of birds: a conversation with Angie Gallinaro - Mapping Edges. Retrieved August 17, 2018, from http://www.mappingedges.org/project/angiegallinaro/

Hill, G., Hill, R., Crosby, A. \& Vanni Accarigi, I. (2018). Learning from neighbours: a conversation with Gordon and Rina - Mapping Edges. Retrieved August 17, 2018, from http://www.mappingedges.org/project/learning-from-neighboursa-conversation-with-gordon-and-rina/

Kidd, J., Crosby, A. \& Vanni Accarigi, I. (2018). Combining colour and scent: a conversation with Jean Kidd - Mapping Edges. Retrieved August 17, 2018, from http://www.mappingedges.org/project/combining-colour-and-smells-aconversation-with-jean-kidd/

Maylon, J. Crosby, A. \& Vanni Accarigi, I. (2018). Haberfield Gardening: a conversation with Jeff Maylon - Mapping Edges. Retrieved August 17, 2018, from http://www.mappingedges.org/project/haberfield-gardening-aconversation-with-jeff-maylon/

\section{Figure List}

Figure 1: Folded subdivision plan: 'The Place of Beautiful Homes' from Haberfield: the garden suburb, Stanton \& Son Limited. [ca. 1913] Sydney, Stanton \& Son

Description: 23 page: ill. (some col.), plan ; 19 x $26 \mathrm{~cm}$.

Digital version available at

http://collection.hht.net.au/firsthhtpictures/fullRecord.jsp?recnoListAttr=recnoList\&re $\underline{\text { cno }=31466}$ accessed August 18, 2018. 
Figure 2: 'Home Gardens of Haberfield'. Map of all gardens that entered the Garden Competition between 2004 and 2017. Map data (C2018 Google 